\title{
Millepora aff. exaesa (Cnidaria, Hydrozoa) Recorded in the Mesophotic Environment of Mount La Pérouse, Southwestern Indian Ocean-Expedition La Pérouse 2019
}

\author{
Emilie Boissin ${ }^{1,2, *} \mathbb{D}$, Chloé Annie-France Bourmaud ${ }^{2,3}$, Laurent Ballesta ${ }^{4}$, Thierry Mulochau ${ }^{5}$ \\ and Nicole Gravier-Bonnet ${ }^{6}$ \\ 1 PSL Research University: EPHE-UPVD-CNRS, USR 3278 CRIOBE, Université de Perpignan, \\ 52 Avenue Paul Alduy, CEDEX, 66860 Perpignan, France \\ 2 Laboratoire d'Excellence CORAIL, 98729 Papetoai, French Polynesia \\ 3 UMR 9220 ENTROPIE, UR-IRD-CNRS-UNC-IFREMER, Université de La Réunion, 55 Avenue René Cassin, \\ CS 92003, CEDEX 9, 97715 Saint-Denis, France; chloe.bourmaud@univ-reunion.fr \\ 4 ANDROMEDE OCEANOLOGIE, 7 Place Cassan Carnon-Plage, 34130 Mauguio, France; \\ ballesta.laurent@gmail.com \\ 5 BIORECIF, 3 ter rue de L'albatros, 97434 La Saline Les Bains, France; biorecif@gmail.com \\ 6 Vie Océane, 6, Avenue d'Aquitaine, 97427 Étang-Salé, France; nickygravier@yahoo.fr \\ * Correspondence: emilie.boissin@univ-perp.fr
}

check for

updates

Citation: Boissin, E.; Bourmaud, C.A.-F.; Ballesta, L.; Mulochau, T.; Gravier-Bonnet, N. Millepora aff. exaesa (Cnidaria, Hydrozoa) Recorded in the Mesophotic Environment of Mount La Pérouse, Southwestern Indian Ocean-Expedition La Pérouse 2019. Diversity 2021, 13, 474. https://doi.org/10.3390/d13100474

Academic Editors: Viatcheslav Ivanenko and Michael Wink

Received: 13 September 2021 Accepted: 24 September 2021 Published: 28 September 2021

Publisher's Note: MDPI stays neutral with regard to jurisdictional claims in published maps and institutional affiliations.

Copyright: (c) 2021 by the authors. Licensee MDPI, Basel, Switzerland. This article is an open access article distributed under the terms and conditions of the Creative Commons Attribution (CC BY) license (https:// creativecommons.org/licenses/by/ $4.0 /)$.
Keywords: mesophotic coral ecosystem (MCE); hydrocoral; hydrozoan; biodiversity; southwestern Indian Ocean

In recent years, mesophotic coral ecosystems have been a growing topic of interest. These mostly unexplored habitats shelter a rich and unique biodiversity [1]. Within the context of global change, they might serve as a source for recolonization after disturbances in shallower reefs. Millepora species, also called fire corals, are important components of coral reefs, and can demonstrate very high local abundance [2]. Because of their calcium carbonate skeletons, Millepora hydrocorals can build large colonies and thus have ecological roles similar to scleractinian corals. Indo-Pacific Millepora species have widespread distributions observed from the surface to $40 \mathrm{~m}$ [2]; very few Millepora species have been recorded below $50 \mathrm{~m}$, and usually from a few imprecise dredging samples [1,3-5]. During an expedition to Mount La Pérouse (Mascarene Plateau, Southwestern Indian Ocean) from 27 October to 5 November 2019, several Millepora colonies were recorded at depths from 59 to $67 \mathrm{~m}$. The colony growth forms were somewhat distinct from the usual growth forms encountered in Réunion Island [6], where three species co-occur: M. cf. exaesa Forsskål 1775, M. cf. platyphylla Hemprich and Ehrenberg 1834 and M. tenera Boschma 1949. Colonies were either encrusting, with small digitations, or massive and unbranched (Figure 1), with numerous scattered vertical swellings of varied diameters and lengths, dome or columnshaped, digitate on top with dactylozooids in extension covering the entire surface like hairs, as is usual on Millepora colonies. Based on the shape of the protuberances, on the color and on the number of dactylopores per cyclosystem, these colonies show affinities with M. exaesa. These records are likely the world's deepest in situ living Millepora colonies ever reported. As we continue to explore more remote places and wider bathymetric depths, our knowledge of species distribution and endemism is being refined, as exemplified by the recent range re-extension of $M$. cf. platyphylla in the Eastern Pacific [7]. 


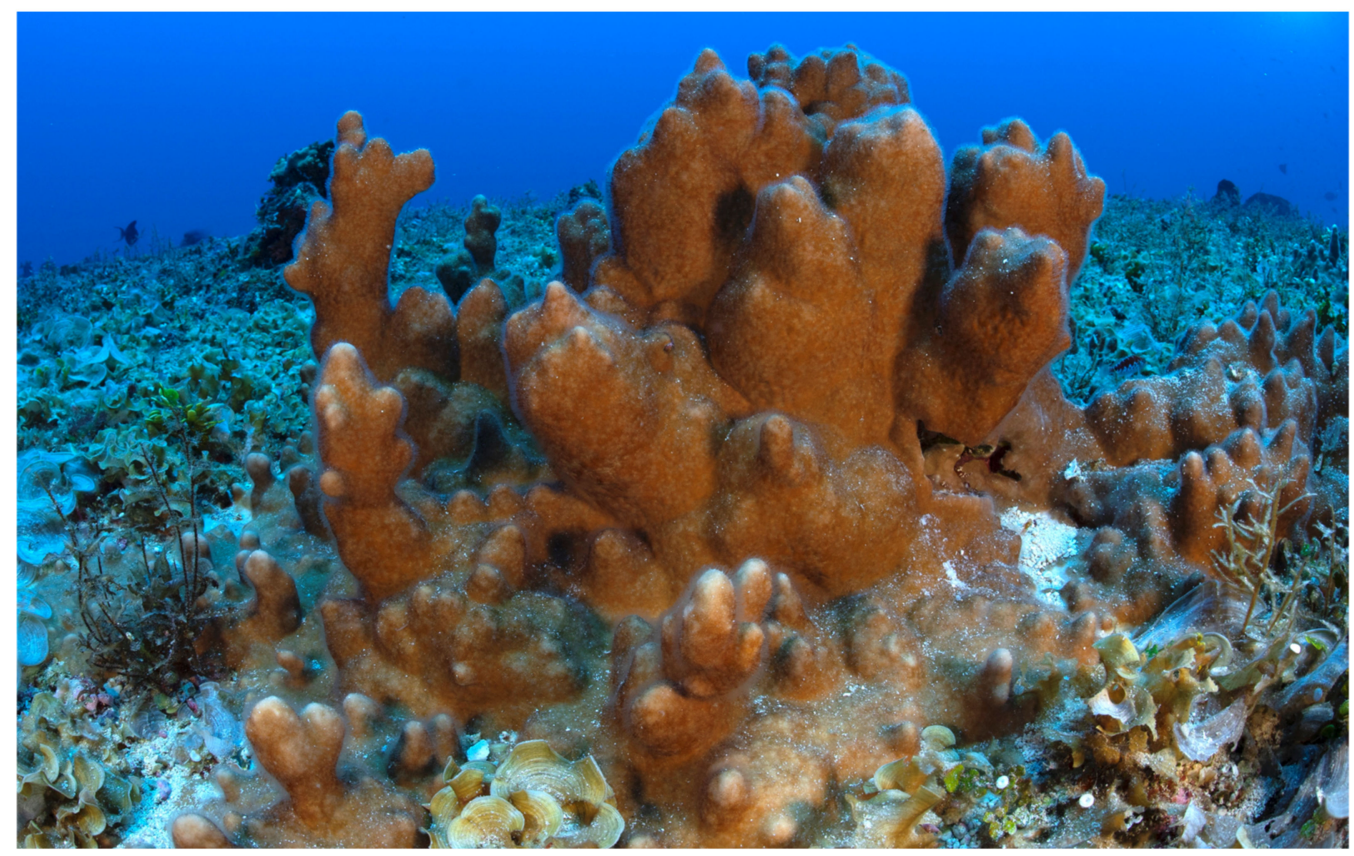

Figure 1. Millepora aff. exaesa at $65 \mathrm{~m}$ on Mount La Pérouse, Southwestern Indian Ocean. Photo credit: Laurent Ballesta/Andromède Océanologie.

Author Contributions: Conceptualization, E.B. and N.G.-B.; methodology, L.B collected images and samples, T.M. processed samples; formal analysis, E.B., N.G.-B.; writing-original draft preparation, E.B.; writing-review and editing, L.B., C.A.-F.B., T.M., N.G.-B.; project administration, T.M.; funding acquisition, T.M., L.B. All authors have read and agreed to the published version of the manuscript.

Funding: La Pérouse Expedition, 2019, was co-funded by the French Gov. (contrat de convergence et de transformation 2019-2022), as well as by sponsors as follows: Vie Océane, Aquarium de La Réunion, Comité Régional d'études et de sports sous-marins de La Réunion, Inset, O Sea Bleu, Fondation du Crédit Agricole Réunion-Mayotte, Fondation d'Entreprises des Mers Australes, Air France, UMR9220 Entropie, Odyssée Créateur de voyages, and by partners of Andromède Océanologie: Manufacture Horlogère Suisse Blancpain, Blancpain Ocean Commitment, RGBlue, Keldan, Topstar, Bigblue, Ap Diving, Molecular, Subspace, Nikon, Aqualung, Seacam.

\section{Institutional Review Board Statement: Not applicable.}

Data Availability Statement: Data sharing is not applicable to this article as no datasets were generated or analyzed during the current study.

Acknowledgments: We would like to thank all of the people involved in the Mount La Pérouse expedition, particularly the divers of Andromede: Florian Holon, Thomas Pavy, Thibault Rauby, Yann Rineau. We also sincerely thank Florence Trentin, from the association Vie Océane, for her involvement in this expedition. Lastly, we would like to thank Sophie and Patrick Durville, who initiated the project.

Conflicts of Interest: The authors declare no conflict of interest. The funders had no role in the design of the study; in the collection, analyses, or interpretation of data; in the writing of the manuscript, or in the decision to publish the results.

\section{References}

1. Loya, Y.; Puglise, K.A.; Bridge, T.C.L. Mesophotic Coral Ecosystems; Springer: Cham, Switzerland, 2019 ; p. 1003.

2. Lewis, J.B. Biology and ecology of the hydrocoral Millepora on coral reefs. Adv. Mar. Biol. 2006, 50, 1-55. [PubMed]

3. Cairns, S.D. Deep-water corals: An overview with special reference to diversity and distribution of deep-water scleractinian corals. Bull. Mar. Sci. 2007, 81, 311-322.

4. Wagner, D.; Kosaki, R.; Spalding, H.; Whitton, R.; Pyle, R.; Sherwood, A.; Tsuda, R.T.; Calcinai, B. Mesophotic surveys of the flora and fauna at Johnston Atoll, Central Pacific Ocean. Mar. Biodivers. Rec. 2014, 7, e68. [CrossRef] 
5. Wells, J.W. Recent corals of the Marshall Islands. Geol. Surv. Prof. Pap. 1954, 260, 385-486.

6. Boissin, E.; Leung, J.K.; Denis, V.; Bourmaud, C.A.F.; Gravier-Bonnet, N. Morpho-molecular delineation of structurally important reef species, the fire corals Millepora spp, at Réunion Island, Southwestern Indian Ocean. Hydrobiologia 2020, 847, 1237-1255. [CrossRef]

7. Boissin, E.; Pogoreutz, C.; Pey, A.; Gravier-Bonnet, N.; Planes, S. Millepora platyphylla (Cnidaria, Hydrozoa) range extended back to the Eastern Pacific thanks to a new record at Clipperton Atoll. Zootaxa 2019, 4668, 599-600. [CrossRef] [PubMed] 